\title{
Harvard Sanat Müzesi’nde Bulunan Minyatürlü Bir Baki Divanı
}

\section{An Illustrated Divan of Baki at the Harvard Art Museums}

\author{
Melis TANER ${ }^{1}$
}

${ }^{1}$ Sorumlu yazar/Corresponding author: Melis Taner, (Dr. Öğretim Üyesi), Özyeğin Üniversitesi, Mimarlık ve Tasarım Fakültesi, İstanbul, Türkiye. E-posta: melis.taner@ozyegin.edu.tr ORCID: 0000-0002-5359-9489

Başvuru/Submitted: 17.04.2019 Revizyon Talebi/Revision Requested: 07.07.2019

Son Revizyon/Last Revision Received: 16.09.2019

Kabul/Accepted: 17.09.2019

Online Yayın/Published Online: 23.10.2019

Atıf/Citation: Taner, Melis. "Harvard Sanat Müzesi'nde Bulunan Minyatürlü Bir Baki Divanı." Türkiyat Mecmuası-Journal of Turkology 29, 2 (2019): 553-576.

https://doi.org/10.26650/iuturkiyat.636803 öz

Bu makale, Bakî Divanı'nın daha önce akademik çalışma konusu olmamış bir nüshasını ele alarak metin-görsel ilişkisini incelemektedir. Minyatürlü divanlar çoğunlukla eserin âşıkane içeriğiyle paralel olarak âşıkları, eğlence veya meclis sahnelerini görselleştirerek eserleri süslerler. Harvard Sanat Müzesi'nde bulunan XVI. yüzyıla ait olan bu Osmanlı eseri, çağdaşı olan diğer Bakî Divanı nüshalarından, minyatürlerinin neredeyse hepsinde şairin figürüne yer verilmiş olmasıyla ayrılır. Bu eserde tasvirlerin metinle çok daha yakın ilişkide olduğu görülmektedir. Bu durum bir yandan da lirik şiiri tasvir etme konusundaki alternatifleri sorgulamamıza vesile olmaktadır.

Anahtar kelimeler: Bakî, Divan, Osmanlı, Minyatür, El yazması, Resimli divan nüshaları

\section{ABSTRACT}

This paper introduces an unpublished, late-sixteenth-century illustrated manuscript of the Divan of Baki (Harvard Art Museums, 1985.273). The manuscript raises the issue of options and paradigms for illustration in the Divan. Taking the Harvard Art Museums manuscript as a point of focus in comparison with the other illustrated Divan of Baki of the late-sixteenth century, this paper focuses on the relationship between a non-narrative text and image.

Keywords: Bakî, Divan, Ottoman, Miniature painting, Manuscript, Illustrated divans 


\section{EXTENDED ABSTRACT}

The famed poet Baki became known as the "sultan of poets" during his long career and his poems were often included in anthologies and his Divan was copied widely. Despite the numerous copies of the Divan of Baki and the inclusion of his ghazals in most anthologies of poetry, illustrated copies of the Divan of Baki are scanty. Among these examples (British Library Or. 7084, Bibliothèque nationale de France Supp. turc 356, Museum of Turkish and Islamic Art T. 1959, and three detached folios coming from a single manuscript: Metropolitan Museum of Art 45.174.5, 25.83.9, RISD Museum 17.459), the seven paintings in the Harvard Divan are unique for their emphasis on the poet and their close connection to the poetry of Baki. These paintings reflect both on particular motifs of the lyric poetry and its mood. Rather than marking the ends of individual odes, or the beginning of a new set of ghazals - as is the case with the majority of illustrated divans - the paintings of the Harvard manuscript interact in a more fluid way with the text. As the Harvard manuscript has not been studied previously, this article provides a preliminary analysis into its paintings and their relationship to the text.

The manuscript contains seven almost full-page paintings that come from the same hand. The first painting represents a youth carving a mountain and an older man shown in profile, with the distinguishing feature of a prominent nose. The ghazal that accompanies this painting begins with a description of spring and ends with the effects of love and of the beloved on the lover. The final couplet compares the poet with the legendary character Farhad, of Khusraw and Shirin of Nizami. The following painting also shows a close relationship to the text where it makes a specific reference to drinking as the painting shows a youth and an older man in a lush garden setting. The next painting similarly depicts the poet (again with his prominent nose) and the youth. This painting, like the previous one, follows the visual convention of juxtaposing the fashionable youth and an old man as the beloved and the lover, respectively. In addition to this visual convention, the composition appears to draw from the breakline couplet: "It is the place of pleasure and desire, let us dance / Let us shake the arches and porticoes, come hither." The poet/old man appears in a pose redolent of dance in the painting. The following painting also takes a line from the ghazal and elaborates on one of its motifs. In the painting, a tall youth holds a bow and arrow. Facing him is a middle-aged man who bares his chest as the youth takes aim, echoing the line above the painting: "My heart, struck many a time, I held towards you." Instead of the target on the left, the middle-aged man tears open his garment at the chest for the youth to take aim at. The next painting again depicts the poet, a youth, and in this case, a dervish wearing a tall, brown cap. In the poem, the poet is urged to expend his breath on gratification and pleasure. The inclusion of a dervish in this painting is perhaps a visual reminder to the poet. The final painting, smaller than the other six paintings, is the most straightforward painting of the manuscript - it represents two youths seated outside, and as a whole it encapsulates the literary universe of the ghazal. Such 
scenes are frequently found in illustrated non-narrative texts. Finally, meant to appear in the first section of the Divan (in the ode to Murad III), but placed haphazardly in the manuscript, is a representation of the arrival of the Safavid prince Haydar Mirza.

This manuscript, taken within the corpus of illustrated divans urges us to look for possible options and paradigms for illustrating non-narrative texts. In dealing with a narrative text, the tendency has been to match the painting with a story, reading the "narrative painting" together with the text. When it comes to non-narrative texts, we can expect certain motifs, such as lovers in a landscape, indoor or outdoor gatherings, games of polo, hunting, etc. that may use a certain word or phrase from the text as a source of inspiration. In the context of lyric poetry, the different options we have of studying the book as a whole and studying how paintings may deviate from "expected forms of decoration" allow us to think further about illustrating a non-narrative text. 


\section{Giriş}

Harvard Sanat Müzesi'nde bulunan XVI. yüzyıla ait bir Bakî (1526-1600) Divan'1, bugüne kadar hiçbir akademik çalışmaya konu olmamıştır. ${ }^{1}$ Bu makale, söz konusu eseri tanıtarak lirik şiirlerin tasvirlerle desteklenmesi konusunu ele almaktadır. Öncelikle eserin somut özellikleri ve konusu açıklandıktan sonra, metin-görsel ilişkisi derinlemesine tetkik edilmiştir.

Bakî, Fatih Camii müezzinlerinden Mihmid Efendi'nin oğludur. Medrese eğitimi boyunca Nev'î (1533-1599) ve Vâlihî (öl. 1588) gibi şairlerle ve Şeyhülislam Hoca Sadeddin’le (1536-1599) tanışma firsatını bulmuştur. Uzun kariyeri boyunca hem şairler, hem de Osmanlı devletinin yüksek mertebesindekilerle yakın ilişkiler içinde olan Bakî, daha hayattayken sultanü'ş-şuara (şairler sultanı) unvanını almıştır. ${ }^{2}$ İlk olarak Sultan Süleyman döneminde (sal. 1520-1566) tertiplenen Bakî Divanı, II. Selim (sal. 1566-1574), III. Murad (sal. 15741595) ve III. Mehmed (sal. 1595-1603) dönemlerinde de şairin yazdığı yeni şiirlerin ilave edilmesiyle yeniden tertiplenmiştir. ${ }^{3}$ Döneme ait benzer divanlar gibi, Bakî Divanı da sultanları metheden kasidelerle başlar. Yalnız sultanlara değil, dönemin önde gelenlerine de kasideler yazmıştır Bakî. Mesela, Sadrazam Semiz Ali Paşa (öl. 1565), Halep Beylerbeyi Kubad Paşa (öl. 1558-59) ya da Şeyhülislam Ebussuud Efendi’ye (1491-1574) de kasideler yazmıştır şair. Kasidelerin ardından musammatlar gelir. Divan, alfabetik olarak sıralanmış gazellerle devam eder. Kitalar ve matlalar divanın sonunda yer alır. ${ }^{4}$

Bakî'nin şiirleri pek çok şiir mecmuasında yer almış ve kendi divanı da pek çok kere kopyalanmıştır. Bugün Bakî Divanı'nın, Türkiye'de ve yurt dışında yüzü aşkın el yazma kopyası olduğu bilinmektedir. ${ }^{5}$ Bu kadar çok el yazma nüshası olmasına ve gazellerinin pek çok mecmuada yer almasına rağmen, Bakî Divanı'nın minyatürlü nüshaları çok azdır. Bu makalenin konusunu oluşturan Harvard Sanat Müzesi nüshası dışında Bakî Divanı'nın üç tane Osmanlı, bir tane de Safevi dönemine ait minyatürlü nüshaları mevcuttur. Bunlar; Britanya Kütüphanesi'nde (Or. 7084) bulunan, XVI. yüzyılın sonlarına tarihlenebilen Bakî Divan'ını ve Priştineli Mesihî (öl. 1512) Divan'ının başlangıcını kapsayan bir nüsha; Fransa Millî Kütüphanesi'nde (Supp. turc 356) bulunan, minyatürleri tamamlanmamış 1595 tarihli bir kopya ve Türk ve İslam Eserleri Müzesi’ndeki 1595 tarihli el yazmasıdır. Bunların dışında üslup ve ebatlar itibariyle tek bir el yazmasından çıktığı anlaşılan, ancak şu an farklı müzelerde bulunan üç müstakil sayfa, bir tane daha minyatürlü Divan nüshasının varlığına işaret eder. Bu XVI. yüzyıl örneklerinin dışında, XVII. yüzyıl ortası Safevi sanatına örnek

\footnotetext{
Bakî Divanı, Harvard Art Museums, 1985, 273.

2 Fuad Köprülü, "Bakî," İslam Ansiklopedisi 2 (1961): 243-253, 243; Mehmet Çavuşoğlu, "Bakî," Türkiye Diyanet Vakfi Islâm Ansiklopedisi 4 (1991): 537-540.

3 Mehmet Çavuşoğlu, "Bakî," Türkiye Diyanet Vakfi Islâm Ansiklopedisi 4 (1991): 537-40.

4 Bakî Divanı'nın muhteva ve çerçevesi için bakınız, Haluk Aydın, "Muhtevanın Çerçevesi-Çerçevenin Muhtevası: Bakî Divanı Örneği," Prof. Dr. Mine Mengi Adına Türkoloji Sempozyumu (20-22 Ekim 2011) Bildirileri, (Adana: Çukurova Üniversitesi Türk Dili ve Edebiyatı, 2010), 41-51.

5 Sabahattin Küçük, Bāḳ̄ Dīvānı (Tenkitli Basım) (Ankara: Türk Dil Kurumu Yayınları, 2011), viii.
} 
olan bir kopya da Britanya Kütüphanesi'ndedir (Add. 7922). ${ }^{6}$

Bu örnekler arasında Harvard Sanat Müzesi’nde olan Bakî Divanı, içindeki minyatürlerde şaire özellikle yer vermesi ve bu minyatürlerin şiirle kurduğu yakın ilişki açılarından eşsizdir. Bu minyatürler, lirik şiirin hem motifleri, hem de şairane tarzına birer yorum olarak düşünülebilir. Yukarıda sözü edilen diğer nüshalardan farklı olarak bunlar, belirli kasidelerin başında ya da sonunda veya alfabetik olarak düzenlenmiş gazellerde bir harfin başlangıcı veya sonuna yerleştirilmiş tasvirlerden değildir. Aksine, Harvard Sanat Müzesi el yazmasının minyatürleri metinle çok daha dinamik bir etkileşim içindedir.

\section{Eserin Özellikleri}

Harvard Sanat Müzesi nüshası nispeten küçük boyutludur (17,3 x $10 \mathrm{~cm})$. Eserin iç kâğıdında silik ve yer yer lekelenmiş iki beyit yer alır. Beyitler ne Bakî’ye ait gibi görünmektedir, ne de şairin şiirlerine bir naziredir. Acemi biri tarafından kaleme alınmış gibi görünür. Yazı biçimi ve dili itibariyle daha geç bir tarihte yazıldığı düşünülebilir ki eserin bir noktada sahibi olan Seyyid Mehmed Emin Vahîd Efendi’ye (öl. 1828) ait olması ihtimal dâhilindedir. Harvard Sanat Müzesi yazmasında bu sefirin şahsi mührü ve 1798-99 tarihi (H 1213) yer almaktadır. ${ }^{7}$ Bu beyitlerin dışında eserin iç kâğıdında ayrıca Bakî’ye hayır duası da yer alır.

Şu anki hâliyle başlangıç sayfasında unvan bulunmaz. Yukarıda da bahsedildiği üzere Bakî Divanı'nın alışılagelmiş düzeni, Kanuni Sultan Süleyman'dan III. Mehmed'e kadar olan padişahlar ile sadrazam ve şeyhülislam gibi o dönemin önemli şahıslarına yazılmış kasidelerle başlar. Kasideleri musammat ve gazeller takip eder ve divan, kıtalarla sona erer. Harvard Sanat Müzesi'ndeki Bakî Divanı Sultan Süleyman için yazılmış olan mersiyeyle

6 Norah Titley, Persian Miniature Painting and Its Influence on the Art of Turkey and India: The British Library Collections (London: The British Library, 1983); Özlem Yıldız, Text and Image in the Divan of Baki: An Illustrated Manuscript in the British Library (Add. 7922) (MA Thesis, School of Oriental and African Studies, 2018).

7 Seyyid Mehmed Emin Vahid Efendi, III. Selim (h. 1789-1807) zamanında, 1806 yılında, Fransa’ya elçilikle görevlendirilmiştir ve Sefaretnāme-i Fransa isimli bir eseri vardır. Seyyid Mehmed Emin Vahid Efendi 1806'daki bu görevinden sonra daha defter emini, 1809'da reisülküttab vekili olmuştur. Ancak bu görevinden üç ay sonra uzaklaştırılarak Kütahya'ya sürgüne gönderilmiştir. Burada daha sonra, 1811'de, bir kütüphane kurmuştur ve bu kütüphane, 1812'de halka açılmıștır. Şair Ayıntaplı Ayn̂̂’nin (öl. 1837) kütüphanenin kuruluşu için yazdığı tarihlere bakarsak çoğunlukla öğrencilere yönelik bir kütüphane olduğunu anlarız. Ayıntaplı Aynî aynı zamanda kurucuyu da bir "zât-1 vâlâ" [yüce insan] olarak belirtir.

Harvard yazmasındaki 1799 tarihli mühür, Seyyid Mehmed Emin Vahid'in kütüphanesini kurmadan önce de kitaplara olan merakını gösterir. Hatta Sefaretnāme-i Fransa'sında da Viyana'da, aralarında üç adet Kuran, bir Kașìde-i Bürde ve IV. Mehmed (h. 1648-87) dönemine kadar olan Osmanlı sultanlarının resimlerini içeren bir albümün de bulunduğu üç yüz bin adet kitap olan bir kütüphaneden bahseder.

Sefāretnāme'sinde bahsi geçen detaylar dışında aynı zamanda Seyyid Mehmed Emin Vahid'in kütüphanesinin yayımlanmamış kataloğu da (Vahid Paşa Kütüphanesi, No: 1031) ne tür kitaplara ilgi duyduğunu gösterir. Bu katalogdan görebileceğimiz üzere oldukça geniş alandaki konulara ilgi duymaktadır.

Mehmet Arslan, Antepli Aynî Divanı (İstanbul: Kitabevi, 2004), 325-326; Sefāretnāme'si için bakınız, Relation de l'Ambassade de Mohammed Seid Wahid Effendi (Paris: Firmin Didor, 1843); Seyyid Mehmed Emin Vahid Efendi'nin kütüphanesi için bakınız, İsmail Hakkı Uzunçarşı1ı, Bizans ve Selçukiylerle Germiyan ve Osman Oğulları Zamanında Kütahya Şehri (İstanbul: Devlet Matbaası, 1932). 
başlar; padişahlara yazılmış kasideler ve elif ile re arasındaki harflerle biten gazeller eksiktir. Metin talik hatla iki sütun hâlinde on yedişer mısra şeklinde yazılmış, her bir gazel bitiminde bir satır aralığı boşluk bırakılmıştır. Bu eserdeki satır sayısı ile eksik olan kaside ve gazeller hesaba katıldığında eserin başında yaklaşık yirmi sayfanın eksik olduğu tahmin edilebilir. Başlangıcı eksik olan bu eser belli ki yeniden ciltlenmiştir.

Sayfa sayıları belirtilmemiştir ancak bir tek sayfa dışında eser düzgün bir sırayı takip eder. Bu müstakil sayfada Safevi şehzadesi Haydar Mirza'nın (öl. 1595) İstanbul'a gelişini gösteren bir tasvir vardır (Resim 1). III. Murad'ın saltanatı sırasında yaşandığg bilinen bu ziyaret, Bakî’nin padişaha yazdığı kasidesinde yer alır. Dolayısıyla eserin başında yer alması beklenirken eserin içine gelişigüzel yerleştirilmiştir.

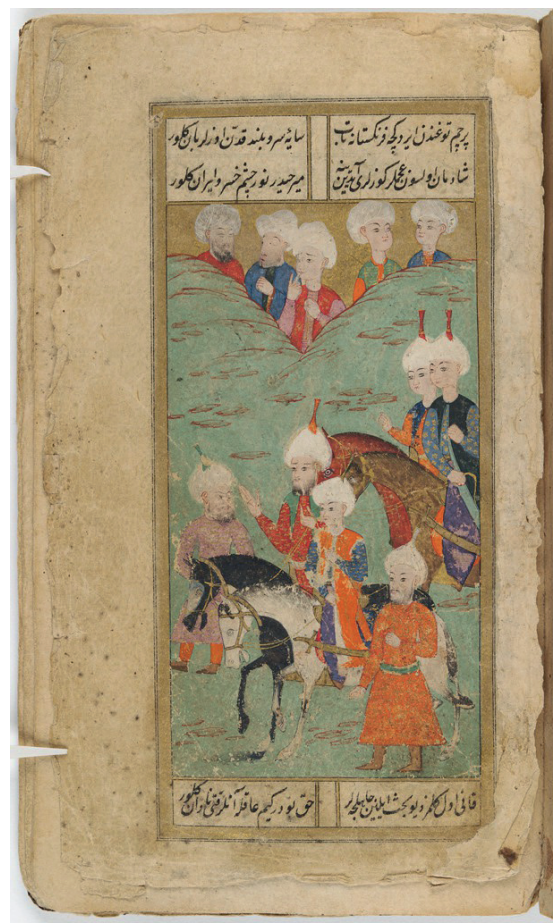

Resim 1: Haydar Mirza'nın Istanbul'a Gelişi, Divan-ı Baki, Harvard Art Museums 1985.273

Osmanlılar ile Safeviler arasında 1578'den 1590'a kadar süren savaşın sonunda barışı garantilemek amacıyla Haydar Mirza, Safevi başkenti Kazvin'den İstanbul'a gönderilmiştir. Şehzâde'nin İstanbul'a gelişinin pek çok şair ve tarihçinin ilgisini çekmiş olduğu, bazı şiirlerin yanı sıra tarih kayıtlrından da anlaşılmaktadır. Bakî de III. Murad'a yazdığı kasidesinde bu konudan bahseder. Harvard Sanat Müzesi'ndeki nüshanın hamisi ya da nakkaşı da benzer şekilde olaya kayıtsız kalmaz. Bu durum eserin en azından 1590'dan sonra tamamlanmış olduğuna işaret eder. 
Yine XVI. yüzyılın sonlarında tasvirlerle süslenmiş bir başka Bakî Divanı (Britanya Kütüphanesi, Or. 7084, varak 1a) örneğinden yola çıkarak Harvard nüshasındaki bu eksik yirmi sayfa içerisinde Britanya Kütüphanesi nüshasında olduğu gibi bir giriş minyatürü ve/ veya kaside kısmında bir veya birkaç minyatür daha olması muhtemeldir. Ancak, bugünkü mevcut durumunda Harvard Sanat Müzesi'ndeki Divan' da yaklaşık tam sayfa ve aynı elden çıkmış gibi görünen yedi adet minyatür yer alır.

\section{Minyatürler}

Bunların ilkinde (Resim 2) morumsu-mavimsi bir dağı, baltasıyla kazan bir genç ve kır sakallı, sarıklı bir adam tasvir edilmiştir. Bu adam sol elinde bir kitap tutarken sağ eliyle gence doğru işaret etmektedir. Genç ise parlak turuncu bir kıyafet ve etrafı sırmalı kumaşla sarılı bir takke giyer. Sol alt köşede ise, kayalıkların arasında ilginç bir yapı belirir.

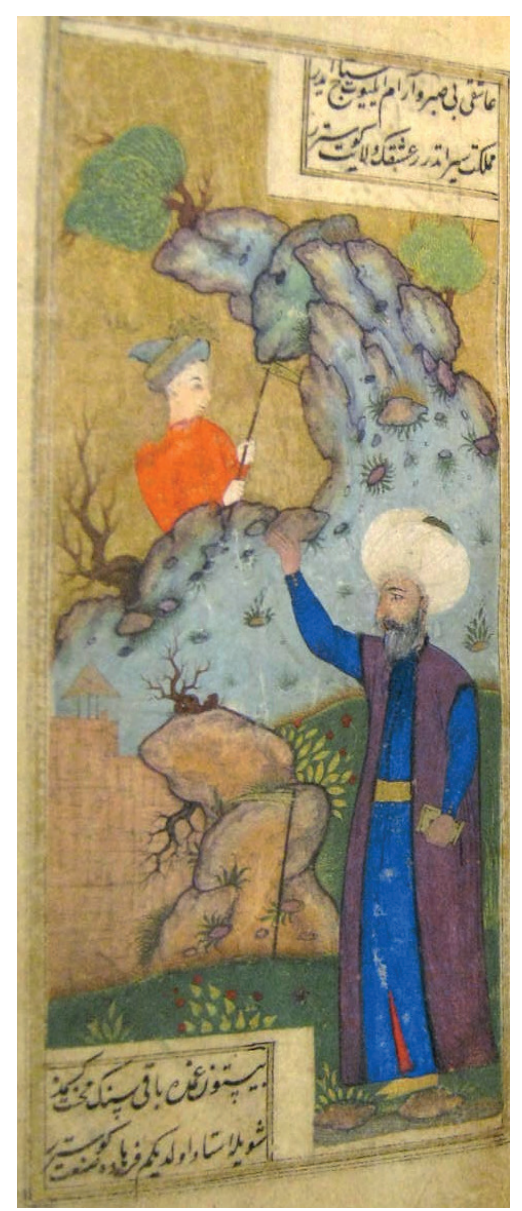

Resim 2: Şair ve dağı delen genç, Divan-ı Baki, Harvard Art Museums 1985.273 
Genç ile yaşlı erkek figürlerine lirik şiirleri süsleyen minyatürlerde sıklıkla rastlanır. Bu minyatürler şiirin lirik içeriğine âşıkane bir anlam katar. Harvard Sanat Müzesi nüshasının ilk minyatüründe yer alan, profilden görülen ve özellikle burnu ile dikkat çeken bu yaşlı adam figürü eserin diğer minyatürlerinde de okurun karşısına çıkacaktır. Minyatürlü divan örnekleri bağlamında düşünüldüğünde lirik şiirlere eşlik eden tasvirlerdeki yaşlı adam genellikle âşık figürünü yansıtmaktadır. Ancak Harvard Sanat Müzesi nüshası özelinde bakıldığında eserin diğer minyatürlerinde de tekrarlanan bu belirgin yaşlı adam şair tiplemesini de yansitıyor olabilir. Elindeki kitabı da bu görüşü destekler niteliktedir. Hatta belki de şair kendini tasvir etmiştir. Görüldüğü gibi lirik şiirlerin mümkün kıldığ eşlik eden resimler için de geçerli olmaktadır; yani bu tasviri hem şair hem de âşı olarak algılamak mümkündür. Bu çok anlamlılık, hem şiiri ve hem minyatürü mana açısından daha da zenginleştirir.

Resmin karşı sayfasında ise baharı tasvir eden bir gazel bulunur:

Mevsim-i gül 'îd ile yâr u musâhib düşdiler Bir birine iki dil-berdür mahabbet gösterür 'Îdgehde varalum dûlâba dil-ber seyrine Görelüm âyîne-yi devrân ne sûret gösterür Kaddüñe kul olmaga gelmiş dizilmiş karşuña Servler turmış çemen sahnında kâmet gösterür 'Âşıkı bî-sabr u ârâm eyleyüp seyyâh ider Memleket seyr itdürür 'aşkuñ vilâyet gösterür Bî-sütûn-1 gamda Bâkî seng-i mihnet kesmede Şöyle üstâd oldu kim Ferhâd'a san' at gösterür.

Şair, okuyucuyu dönme dolaptaki güzellere bakabilmesi ve baharın tadını çıkarabilmesi için bayram yerine gitmeye teşvik eder. Orada, serviler âşı ğa hürmeten karşısında dizilmiş̧tir. Şair, gazelin ilk kısmında çevredeki doğaya atıfta bulunurken ikinci kısımda maşuğun, âşığın iç dünyası üzerindeki tesirini dile getirir. Maşuğu görmek âşığı sabırsız, huzursuz eder, onu bir seyyah gibi sürükler. Resimle aynı sayfayı paylaşan son beyitte de şair, kendisini Ferhad'la kıyaslar. Bu son beyitte bahsi geçen Ferhad, Genceli Nizamî’nin (1141-1209) acıklı hikâyesi Hüsrev ile Şirin' deki aşk üçgeninin bir ayağı olan Ferhad'dır. Bu eserdeki diğer iki kahraman da Sasani hükümdarı Hüsrev Perviz ve Ermen prensesi olan Şirin'dir. Hüsrev de, Ferhad da Şirin'e âşık olunca hükümdar, Ferhad'a neredeyse imkânsız bir görev verir ve Bisutun Dağı'nı delmesini ister. Ferhad bunu başarır ancak Hüsrev, Ferhad'a Şirin'in öldüğü haberini gönderir. Bu haberi alan Ferhad, üzüntüsünden kendini dağın tepesinden atar.

8 Bakınız Dominic Parviz Brookshaw, Hafiz and His Contemporaries: Poetry, Performance\&Patronage in Fourteenth-Century Iran (London, New York: I. B. Tauris, 2019); Priscilla Soucek, "Interpreting the Ghazals of Hafiz" RES: Anthropology and Aesthetics 43 (2003): 146-163; Mieke Bal and N. Bryson, "Semiotics and Art History" The Art Bulletin 73 (1991): 174-208. 
Bakî’nin minyatürle aynı sayfadaki beytinde geçen "seng-i mihnet kesmede" ifadesi Ferhad'ın hikâyesine doğrudan bir gönderme olup kendisini onunla kıyaslayarak âşı̆̆ın elinden 1stırap çekmedeki hünerini ortaya koyar. Minyatürde de metinde yer alan konu tasvir edilmiştir. Ferhad, dağı delerken bir yandan da yaşlı adam, ona doğru bakar ve işaret eder. Eğer bu yaşlı adam figürünü şair tiplemesi olarak alırsak o zaman Bakî’nin beytinde yazdığı gibi kendisini Ferhad'la kıyaslaması fikri, minyatürde de desteklenmiştir.

İkinci minyatür (Resim 3), şairi/âşığı bir elinde altından kâsesiyle çiçeklerle dolu bir yeşillikte otururken tasvir eder. Figür diğer eliyle bir sürahiye uzanmaktadır. Kırmızı ve mavi giysili bir genç, altından bir tepside taşıdığı meyveleri şaire/âşığa sunar. Figürlerin hemen arkasında yer alan üç servi ağacı bir yandan kompozisyonu dengelerken diğer yandan görsel olarak genç adam ile yaşı adamı birbirinden ayırır. İşret meclisleri ve ziyafetler, lirik şiirleri canlandıran minyatürlerde yaygınken bu bağlamda minyatürden evvel gelen beyit, bu ilişkiyi daha da güçlendirir. Tasvirin canlandırdığı gazel âşıkane olup âşığın maşuğa olan hislerini ortaya koyar ve âşık, maşuğa olan aşkından iki büklüm olur:

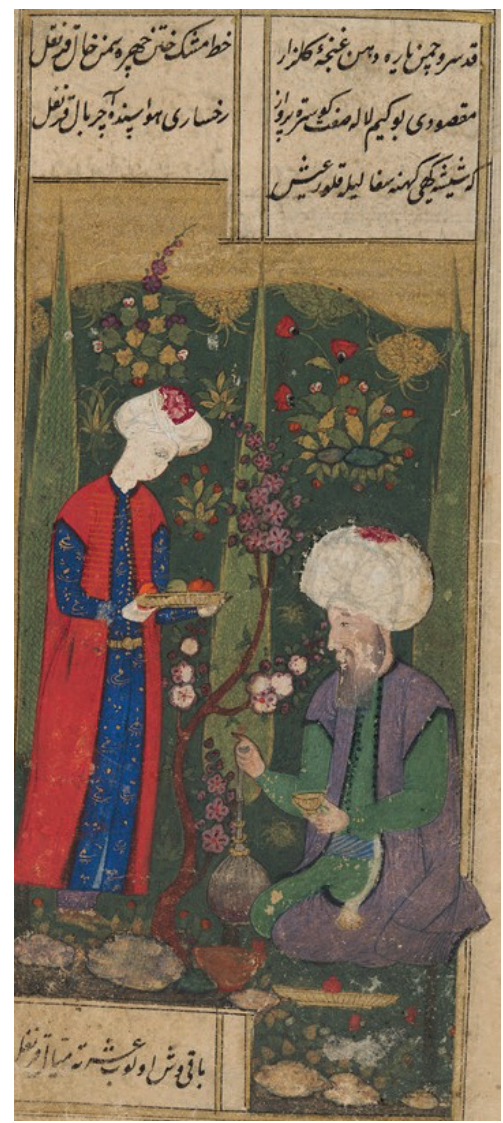

Resim 3: Ayakta duran genç ile şair, Divan-ı Baki, Harvard Art Museums 1985.273 


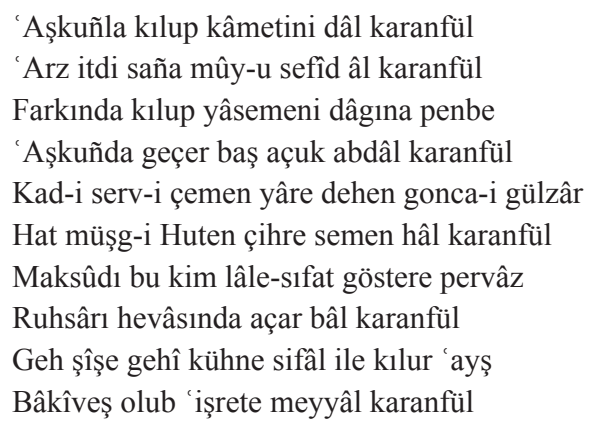

Minyatür âdeta, "Geh şî̧se gehî kühne sifâl ile k1lur 'ayş / Bâkîveş olub 'işrete meyyâl karanfül”" beytini görselleştirir. Açık bir alanda, yeşillikler içinde oturan bir genç ve bir yaşlı; önlerinde bulunan sürahi ve meyve dolu tepsiler, lirik şiirlerin tasvirinde sıklıkla rastlanan sahnelerdir. Burada da bu tipik motif kullanılmıştır. Ama minyatürde görülen yaşlı adam aynı zamanda, sanki boyu bosu dal- harfi gibi eğrilmiş, maşuğa aklaşmış saçlarını sunan şairle kıyaslanabilir mi?

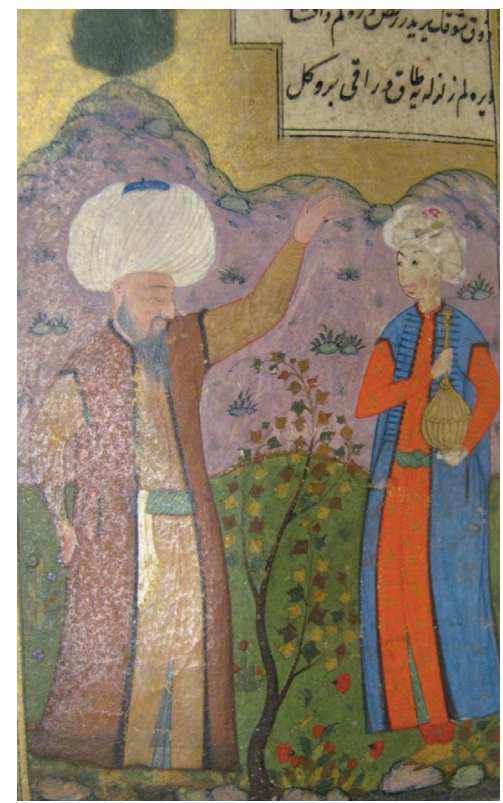

Resim 4: Şair ve genç, Divan-ı Baki, Harvard Art Museums 1985.273

Bir sonraki minyatürde de şair, bir gençle birlikte tasvir edilmiştir (Resim 4). Şairin üzerinde bu sefer uzun, hardal sarısı bir kıyafet ve kolsuz, kürklü kahverengi bir üstlük vardır. Diğer minyatürlerde olduğu gibi başında da geniş sarığı vardır. Profilden gösterildiği için burnu ve uzun kırlaşmış sakalı dikkat çeker. Yanaklarındaki kırışıklıklar, diğer tasvirlerde olduğu gibi bu minyatürde de belirgindir. İlk minyatürdeki gibi kolunu kaldırarak gence 
doğru işaret eder. Neredeyse raks eder gibi bir havası vardır. Turuncu ve mavi bir giysisi olan gencin başında ise daha küçük bir sarık vardır. Elinde altından bir sürahi bulunmaktadır. Şairin sade giysisine göre genç daha iddialı giyinmiştir ve sarığının kıvrımlarına bir çiçek yerleştirmiştir. İkili, lirik şiirde veya minyatürde yaygın olarak işlenen yaşlı adam ile genç âşığı temasını yansıtır âdeta. İkisinin arasında sararan yaprakları olan bir ağaç, sanki şairin bükülmüş kollarını taklit edermişçesine kıvrılır. Minyatürle sayfayı paylaşan beyitler ve gazelin devamı da bu temayı destekler:

Zevk u şevküñ yiridür raks uralum dest-efşân
Virelüm zelzeleye tâk u revâkı berü gel
Sunma la'1-i şeker-efşânuñı bî-zevklere
Eyle şîîn dehen-i ehl-i mezâkı berü gel
Hitta-i Rûm'dadır 'irk-1 nihâl-i ikbâl
Özleme hâk-1 Horâsân u 'Irâk'1 berü gel
Çok tehî devr ide bu sâgar-1 mînâ bizden
Var iken şîşede bâkî hele sâkî berü gel
Umaruz himmet-i merdân-1 tarîkat yitişe
Nâ-gehân bir gün efendüm diye Bâkî berü gel

Şair okuyucuyu (ya da maşuğu) alkışlamaya, el çırpmaya, zevke teşvik eder. Aynı hissin devamıyla içki şişesi boş gezer diye şikâyet eder ve sakiden şişeyi doldurmasını ister. Minyatürde de genç oğlan, bir eli havada olan yaşlı adamın karşısında elinde sürahiyle durur.

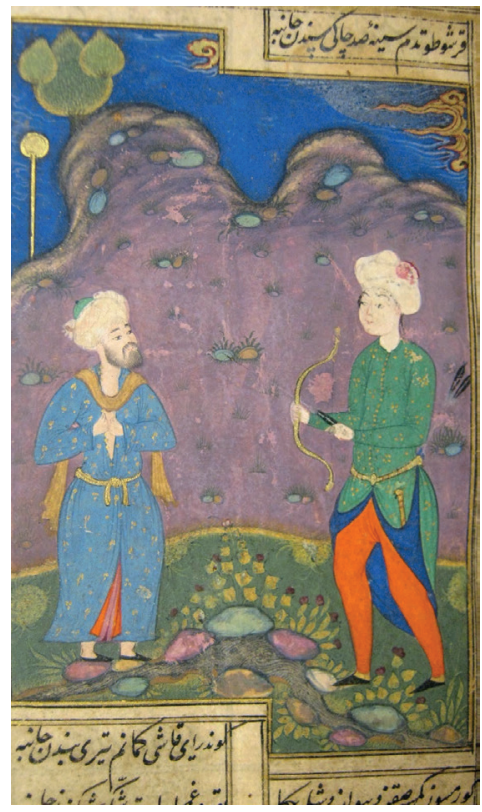

Resim 5: Orta yaşlı adam ile elinde ok ve yay tutan genç, Divan-ı Baki, Harvard Art Museums 1985.273 
Bir sonraki minyatür yine gazelden bir beyitle yakın ilişki içindedir (Resim 5). Minyatürde, elinde bir ok ve yay tutan uzun boylu bir genç ve karşısında orta yaşlı bir adam tasvir edilmiştir; açık mavi giysisinin üzerinde omuzlarına atılmış, uçları arkaya düşen bir şalı ve yeşil takkesinin etrafına sarılı bir sarığı vardır. Genç adam ona doğru hedef almışken göğsünü açması, "Karşu tutdum sîne-i sad-çâki senden cânibe" beytinin görselleşmiş hâli gibidir. Gazel, minyatürün altında şu şekilde devam eder:

\author{
Gönder ey kaşı kemânum tîri benden cânibe \\ Defterin bâd-1 sabâ lü’ lu-yı lâlânuñ dürer \\ İlter olsa dişlerüñ vasfiñ 'Aden'den câbine \\ Görmesün kimse sakın diyü lebiñ dişler baña \\ Bakdugumca ol büt-i şekker-şikenden cânibe \\ Seyr idelden gülşen-i hüsnüñde kadd ü haddüñi \\ Çekmez oldu hâtırum serv u çemenden cânibe \\ Husrevâ yıllar durur yoluñda Ferhâd'uñ geçer \\ Mâ'il ol Bâkî-i şîrîn-suhanden cânibe
}

Minyatürün arka planında, iki tepeli mor bir yükselti görülmektedir. Soldaki daha yüksek tepenin üstünde evvelki tasvirdekine benzer bir ağaç yer alır. Orta yaşlı adam, tepedeki ağacın yakınındaki hedef tahtasının önüne geçmiş, kendisini hedef haline getirmiştir. Minyatürün altındaki beyte uygun biçimde göğsünü açar ve gencin göndereceği oku bekler. Bu minyatür bir yandan gazelin şairane tarzını yansıtırken diğer yandan içeriğiyle de doğrudan alakalıdır. Okun kendisini hedef almasını ister şair ve pare pare olmuş göğsünü ona açtığını söyler. Minyatür de metin de sahip çıkma ve kıskanma hissiyle örülmüştür. Âşık, maşuğunun tek sahibi olmak ister, kimsenin onu görmesini istemez. Minyatür ilk beyte gönderme yapar ama gazelde aynı zamanda Hüsrev’e, Ferhad'a ve Şirin'e de göndermeler vardır. Böylece el yazmasındaki minyatürler arasında da bir bağ kurulmuş olur. Bakî'nin şiirinde Hüsrev, Ferhad ve Şirin gibi bedbaht aşkın kahramanlarına göndermeler yaygındır. Ancak birinci minyatür (Resim 2) ve bu tasvirin özellikle bu gazel için seçilmiş olması, genel olarak aşkla ve aşkın âşığa yaptırdıklarıyla ilgili bir yorum olarak eserin tümüne yönelik bir bütünlük sağlama çabasıdır. Belki de bu resimdeki gencin uzun boyu, uzun boylu Ferhad'a ve şirin sözlü şair de Şirin'e bir göndermedir. Bir şekilde âşı ile maşuk arasındaki ilişki de tersine çevirilmiştir. Yani bu sefer belki âşı gençtir ve âşık olunan da orta yaşlı adamdır. Hikâyeyi bir olaylar silsilesine bağlı olarak anlatmak yerine, bir durumu anlatan gazellerin yahut genelde lirik şiirin tasvir edilmesi, böyle çoklu okumalara imkân vermesi açısından son derece dikkat çekicidir.

Bir sonraki minyatüre (Resim 6), üç sayfa sonra rastlanır. Profilden çizildiği için kemerli burnuyla dikkat çeken ve diğer iki figürden daha büyük tasvir edilen şair, bu sefer hardal sarısı ve kahverengi sade giysisi ve yeşil takkenin etrafında sarığıyla yeşillikte otururken görülmektedir. Sol elinde bir meyve tutarken sağ eliyle karşısındaki gencin elindeki kâseye 
işaret eder. Genç sakinin arkasında, minyatürün sol kenarında, ayakta duran ve sakiyle şairi izleyen bir Mevlevi dervişi yer almaktadır. Figürler açık havadadır. Arka planda eflatun renkli tepecikler ve bunların arasında dalları hafif eğimli, yaprakları sararmaya başlamış bir ağaç bulunur. $\mathrm{Bu}$ el yazmasındaki neredeyse her minyatürde olduğu gibi bu örnekte de gökyüzü altın rengindedir. Gökte sol tarafta mavi, beyaz ve kırmızı alevimsi bulutlar resmedilmiştir. Bir önceki sayfada metin diyagonal olarak yazılmış ve minyatürün tam bu noktaya yerleştirilmesi planlanmıştır. Böylece minyatür gazelin son üç beytiyle aynı sayfayı paylaşır:

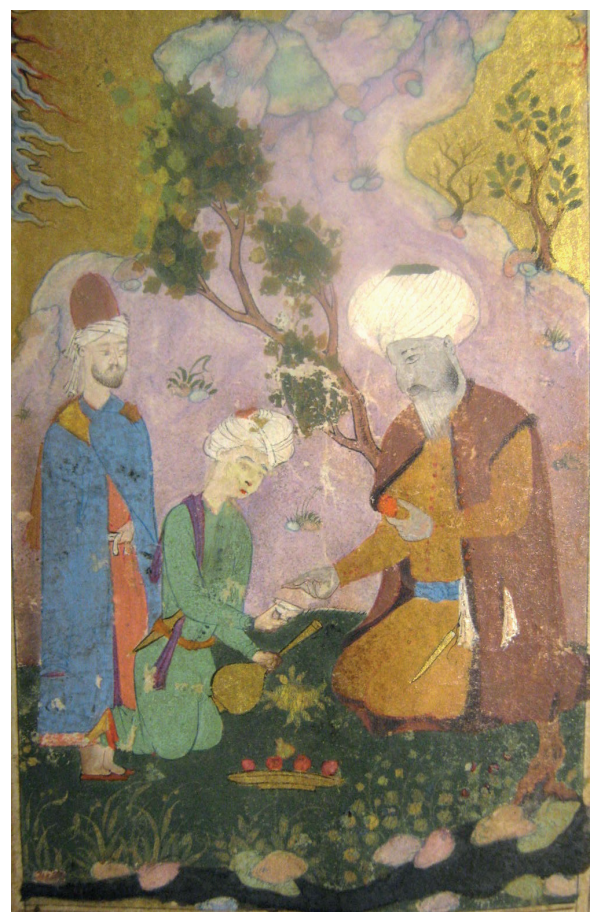

Resim 6: Saki, şair ve mevlevi, Divan-ı Baki, Harvard Art Museums 1985.273
Mey-i lâle-reng elde meclis müheyyâ
Ne hâcet zamân-1 gül u gülsitâne
Ruh-u dil-ber ü câm-1 sâkî nazarda
Ne minnet bahâr u gül u erguvâna
Demüñ 'ayşa sarf eyle Bâkî niyâzuñ
Cevân-baht sultân-1 sâhib-kırâna

Minyatürdeki derviş figürü, sakinin elindeki şişe ve kâseye meyleden şairi görsel olarak dengelerken bir yandan da metinle birlikte düşünüldüğünde, nefesini zevke saklaması söylenen şaire/âşı̆ğa bir hatırlatma olarak değerlendirilebilir. 
Harvard Sanat Müzesi el yazmasındaki son minyatür belki bu eserdeki minyatürler arasında en basmakalıp olanıdır (Resim 7). Gazelin ilk beyitlerinden sonra gelen ve diğer minyatürlerden daha küçük boyutlu olan bu minyatür, dış mekânda oturan iki genci gösterir ve tam üstünde şu beyitler vardır:

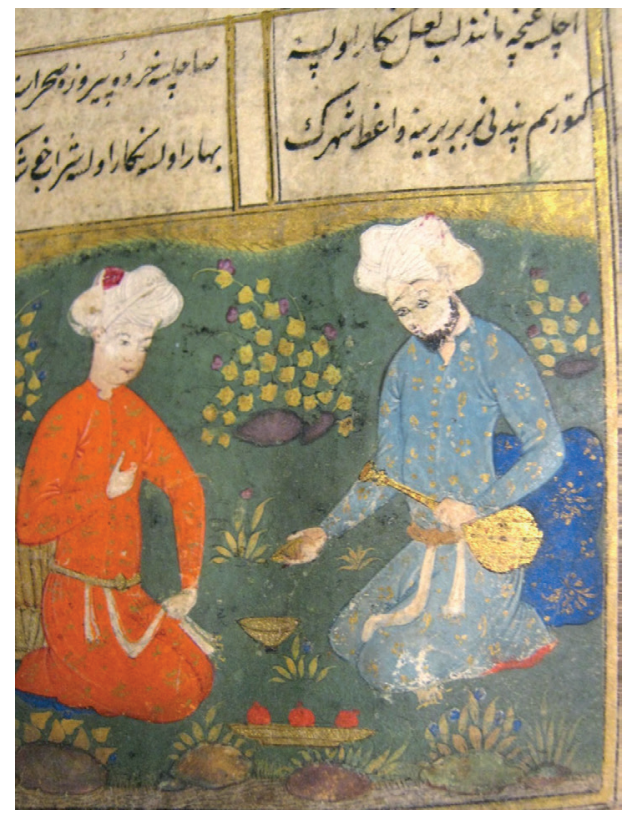

Resim 7: İki genç, Divan-ı Baki, Harvard Art Museums, 1985.273

Açılsa gonca mânend-i leb-i la'l-i nigâr olsa

Saç1lsa hurde-yi pîrûze sahrâ sebzezâr olsa

Getürsem pendini bir bir yirine vâ'iz-i şehrüñ

Bahâr olsa nigâr olsa şarâb-1 hoş-güvâr olsa.

Diğer minyatürlerden farklı olarak bu defa şiir ve minyatür arasında doğrudan bir ilişki yoktur. Daha çok gazelin havasını, belki baharı yansıtır. Pek çok Osmanlı veya Safevi dönemi minyatürlü divanlarda veya mecmualarda bu tür açık havada oturan gençler/âşıklar, şölenler, ziyafetler ya da iç mekânlarda meclis sahnelerine sıklıkla rastlanır. Harvard Sanat Müzesi'ndeki bu Bakî Divanı'nın minyatürleri de aslında gazellerin âşıkane havasını ve edebî motiflerini yansıtır. Bu açıdan Osmanlı ya da Safevi dönemlerinde karşımıza çıkan minyatürlü divanlardan çok da farklı sayılmaz. Ayrıca gazellerin içinde geçen bir kelimeye odaklanmak ve minyatürde bu temayı işlemek de nadir rastlanan bir durum değildir. Sunum ya da işret meclisleri de minyatürlü divanlarda sık sık eserin başında ya da sonunda karşımıza çıkar (mesela aşağıda da bahsedilecek Britanya Kütüphanesi örneğindeki gibi). Bunların ötesinde gazellerin veya farklı bölümlerin arası tezhiple ya da başka tür süsleme örnekleriyle 
ayrılabilir. Böylece okuyucu durup düşünmeye teşvik edilir; aynı zamanda bir şiirin ya da bir bölümün bittiği de görsel olarak vurgulanmış olur.

$\mathrm{Bu}$ el yazmasını diğer minyatürlü Bakî Divan'larından ayıran şey, hem minyatürlerde gazellerin duygu yüklü havasına ve kullanılan edebî motiflere yoğun biçimde yer verilmesi, hem de şairin/âşığın portresinin neredeyse her tasvirde karşımıza çıkmasıdır. Harvard Sanat Müzesi nüshasındaki minyatürler, divanlarda sıklıkla rastlandığg gibi çevgan oyunları, av, işret meclisleri ya da ziyafetleri konu olarak almaz. Ayrıca minyatürler, alışılmış uygulama olan gazellerin bitiş ya da başlangıç noktaları yerine şiirin içinde, metinle ilişkileri göz önüne alınarak konumlandırılmış, tam olarak bulunmaları planlanan yerlerde ve metinle diyalog halinde olacak şekilde yerleştirilmiştir.

\section{Karşılaştırma}

Çağdaşı olan diğer Bakî Divan'ları ile karşılaştırıldığında eserin özel durumu daha da netleşir. Britanya Kütüphanesi'nde bulunan bir Bakî Divan'ının (Or. 7084) ilk sayfasında yer alan açılış resmi, bir kasrın bahçesindeki şiir meclisini konu alır (v. 1a). Kasrın kapı

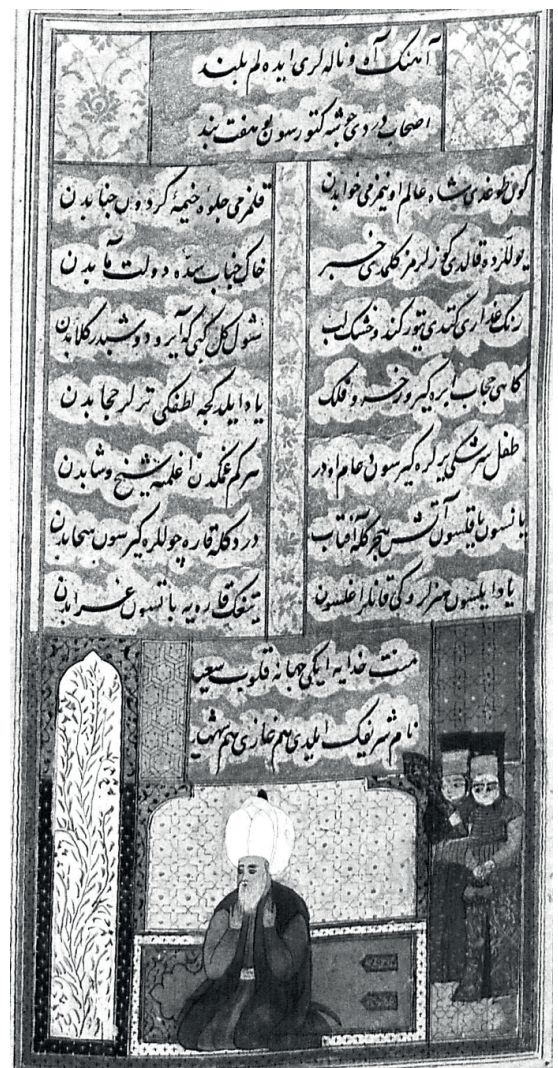

Resim 8: Kanuni Sultan Süleyman, Divan-ı Baki, British Library, Or. 7084, v. 22a 
kemerinde yazılı beyitler, edebî yaratılış da dahil olmak üzere, yaratılış olgusuna gönderme yapar. Bu beyitler, klasik İran edebiyatının en büyük şairlerinden biri olan Sadi’nin (1213(y)1291) Bostan'ından alınmıştır. Metin, açı1ış minyatürünü takip eden sayfada, Kanuni Sultan Süleyman'a yazılmış bir kasideyle başlar. İkinci minyatür, Kanuni mersiyesinin sonundadır (Resim 8). Hemen ardından gelen diğer bir minyatür ise II. Selim'i tasvir eder (Resim 9). Bu minyatürden hemen sonra gelen beyitler, şairi ve dolayısıyla okuyucuyu, Yaradan'ın aynası olarak tanımlanan padişaha bakmaya yönlendirmektedir. ${ }^{9}$

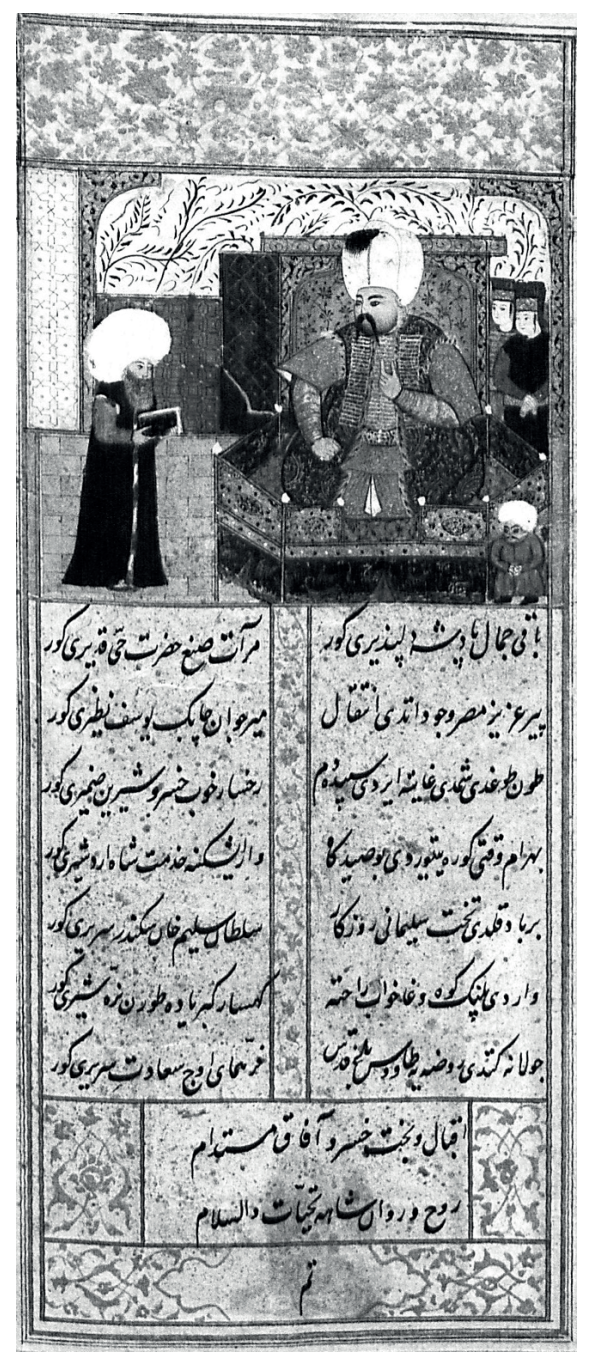

Resim 9: II. Selim, Divan-ı Baki, British Library, Or. 7084, v. 22b

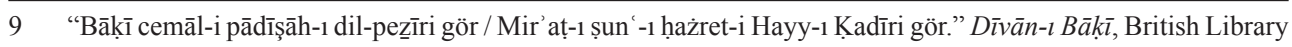
Or. 7084 , v. 22 b. 
Kasidelerden sonra gazeller yer alır. Bu bölümdeki iki resmin ilkinde iç mekânda gerçekleşen bir meclis tasvir edilmiştir. İkinci minyatür nun harfiyle biten gazellerin başında yer alır ve nehir kenarında yıkanan Şirin'i gözetleyen Hüsrev'i resmeder. Divan, ketebe kaydının altına yerleştirilmiş sunuş sahnesini tasvir eden bir minyatürle sonlanır. Sonra III. Mehmed'in tahtta oturuşunu resmeden tam sayfa bir minyatür bulunur (Resim 10). Bu minyatür, Bakî Divanı ile, sonu eksik olan ama aynı cilt içinde bulunan Mesihî Divanı arasında geçiş sağlar.

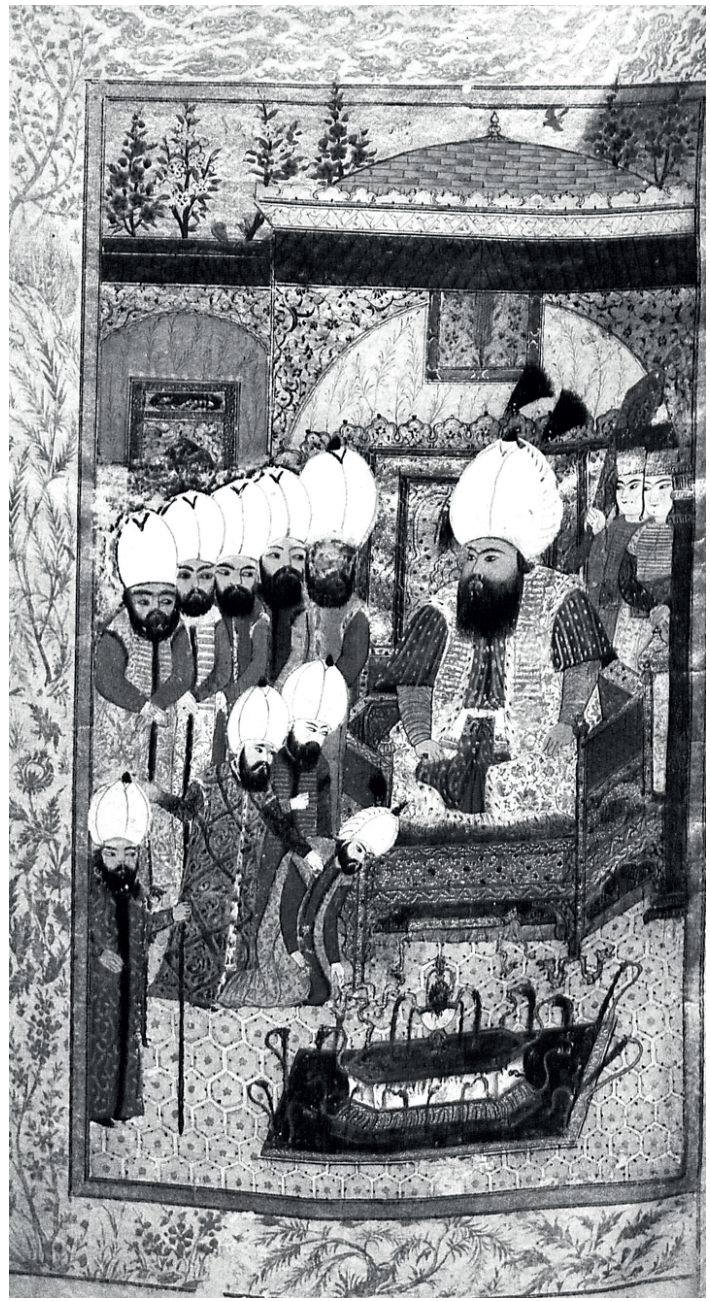

Resim 10 III. Selim, Divan-ı Baki, British Library, Or. 7084, v. 96a

Benzer bir şekilde, Türk ve İslam Eserleri Müzesi’nde bulunan (T. 1959) 1595 tarihli Bakî Divanı, Sultan Süleyman için yazılan kasidenin, Sadrazam Semiz Ali Paşa için yazılmış 
Bahariyye’nin (Resim 11), Halep valisi Kubad Paşa ve Şam kadısı için yazılmış kasidelerin tasvirleriyle süslenmiştir (Resim 12). Bahariyye minyatürü çok canlı bir tabiat manzarası sunar: çiçek açmış ağaçlar, ağaçlara konmuş kuşlar, kıvrıla kıvrıla akan bir dere ve yüzen ördekler... Bir ağacın arkasından bakan bostanc1, resimdeki tek insan figürüdür. Kasidelerden sonra gelen bir minyatür (Resim 13) Bakî’nin, geç XV.-erken XVI. yüzyıl Osmanlı şairi Necati’nin (öl. 1509) bir gazeline yazdığı tahmise eklenmiştir. Tezkire yazarı Âşık Çelebi (öl. 1572) Necati’yi "Rum' da şiirin temelini atan kişi”" olarak tanıtır. ${ }^{10}$ Bahsi geçen tahmiste Bakî

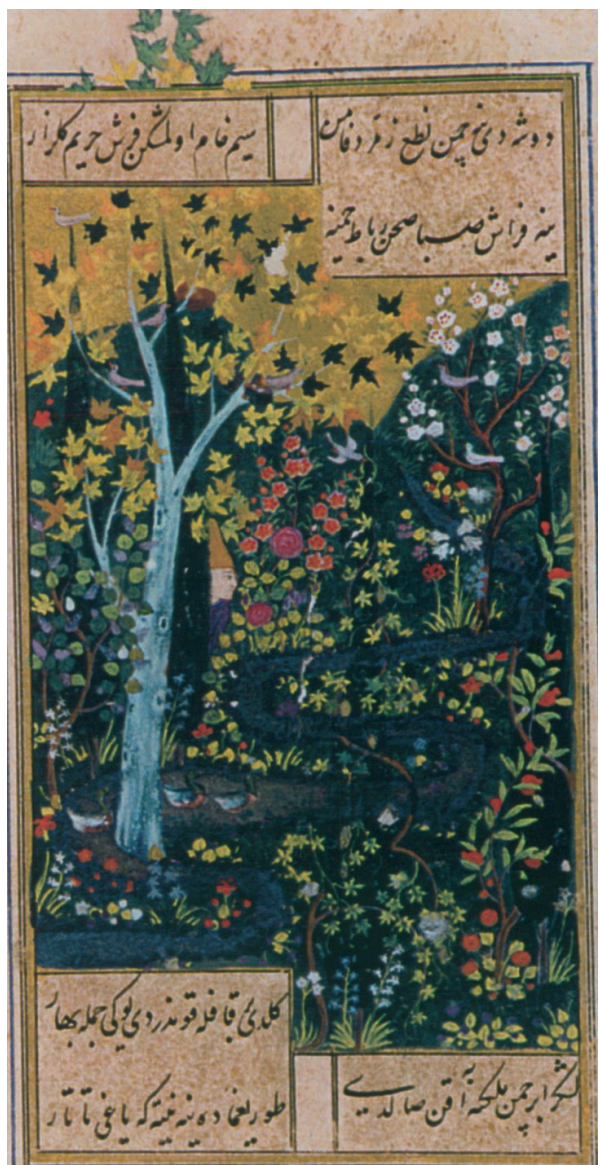

Resim 11: Bahar manzaras1, Divan-ı Baki, Türk ve İslam Eserleri Müzesi T. 1959, v. 13a

10 Âşık Çelebi, Meşāirü'ş̧ Şu 'arā, Millet Kütüphanesi, Ali Emiri 772, v. 355b; Filiz Kılıç, haz. Asşsk ÇelebiMeşairü'ş Şuara (İstanbul: İstanbul Araştırmaları Enstitüsü, 2010), 409-415, 849-860. Şah 'Abbas'ın (sal. 1588-1629) kutüphanecisi ve ressamı Sadıki Bey (ö. 1610) de Mecma 'ü'l Havass isimli eserinde Necati ve Bakî’ye de yer verir ve bu şairler arasında bir bağ kurar ve der ki Necati gibi Bakî de melikü'ş şu 'ara-yı Rum olarak bilinir. Sādiqī Beg, Majma 'al-Khawāṣs, haz. Abd al-Rasūl Khayyampour (Tebriz: Akhtar-1 Shumāl, 1948), 116. 


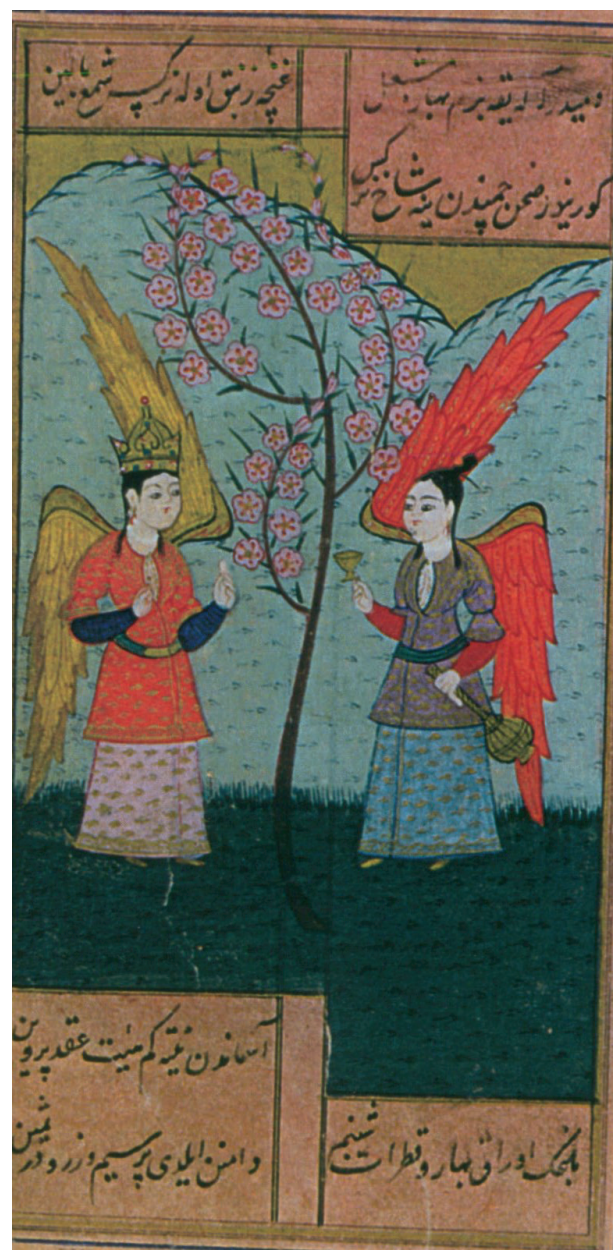

Resim 12: İki melek, Divan-ı Baki, Türk ve İslam Eserleri Müzesi T. 1959, v. 29a

kendisini, melikü'ş şu 'ara olarak nam salmış diğer bir şairle doğrudan karşılaştırmaktadır. Şairin tasvir edildiği bu minyatürde Bakî’nin edebî karşılaştırması ve kendini methedişi vurgulanmaktadır. Tahmisten hemen sonra gazeller başlar ve bu ayrımı tezhipli bir unvan belirtir. Kasideleri ve tahmisi canlandıran minyatürlerden sonra gazeller bölümünde de iki minyatür vardır. Bunlar da yine harf ayrımlarını belirten noktalara yerleştirilmiştir.

$\mathrm{Bu}$ örneklerin dişında Paris’te Fransız Milli Kütüphanesi’nde (Supp. turc 356) minyatürleri bitmemiş bir Bakî Divanı daha mevcuttur. Bu nüshada, yalnızca bir tane bitmiş ancak biraz hasarlı bir minyatür yer alır (v. 9a). Halep valisi Kubad Paşa'ya yazılan kasideye eşlik eden bu minyatürde, elinde kitap olan bir genç ile yazı yazmakta olan beyaz sakallı bir adam vardır. Bunun dışında Şam kadısı Mehmed Çelebi için yazılmış olan kasidenin sonunda da bir minyatür bulunması belli ki planlanmış ancak bırakılan yer boş kalmıştır. Bu Paris 


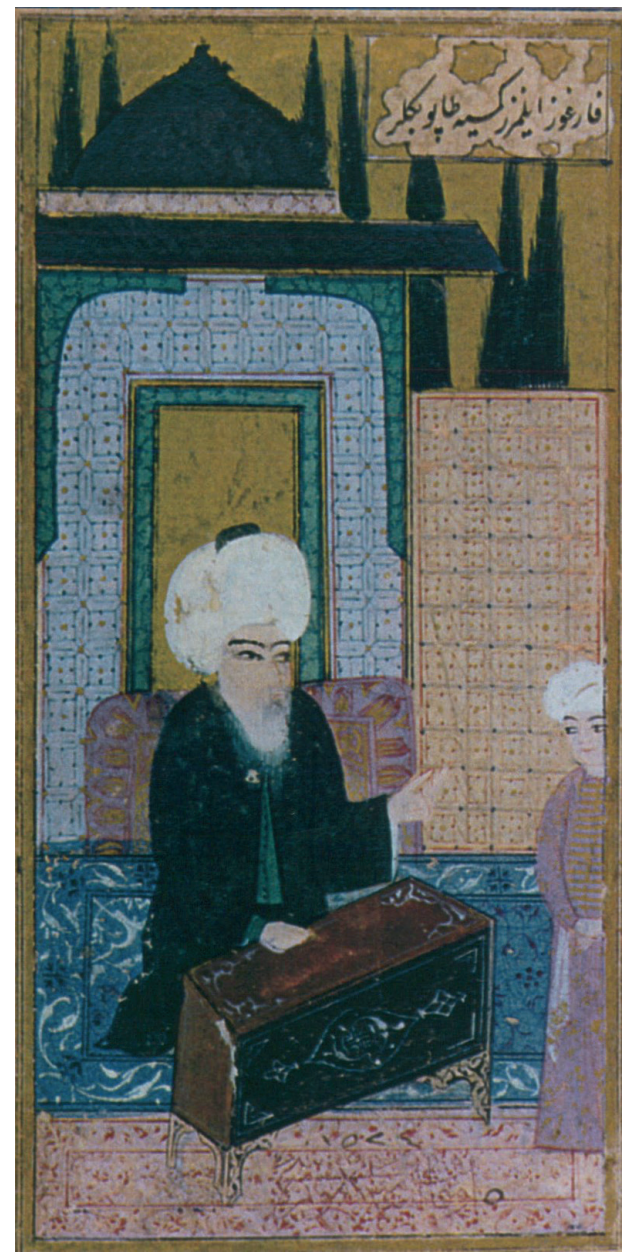

Resim 13: Şair, Divan-ı Baki, Türk ve İslam Eserleri Müzesi T. 1959, v. 38a

yazmasında da yukarıda belirtilen örnekler gibi minyatürlere belirli noktalarda ve özellikle de kaside kısmında yerleştirildiğini görülmektedir.

Yazının başında bahsi geçen tek bir el yazmasından çıkmış üç tek sayfada da minyatürler benzer şekilde kasideleri tasvir eder. Bunların yer aldığı nüsha muhtemelen Bağdat valisi Sokolluzade Hasan Paşa (öl. 1602) için XVI. yüzyılın sonlarında Bağdat eyaletinde hazırlanan bir Bakî Divanı' dır. ${ }^{11}$ Bu üç minyatürden biri (Resim 14), yukarıda bahsedildiği gibi Safevi şehzadesi Haydar Mirza’nın İstanbul'a gelişini konu almaktadır. Altın rengi sarığı ve sorgucuyla doru bir at üstünde şehre doğru ilerleyen genç şehzadenin yanında iki beyaz

11 Zeren Tanındı, "Transformation of Words to Images: Portraits of Ottoman Courtiers in the "Diwans" of Bākī and Nādirī," RES: Anthropology and Aesthetics 43 (2003): 131-145, 134. 


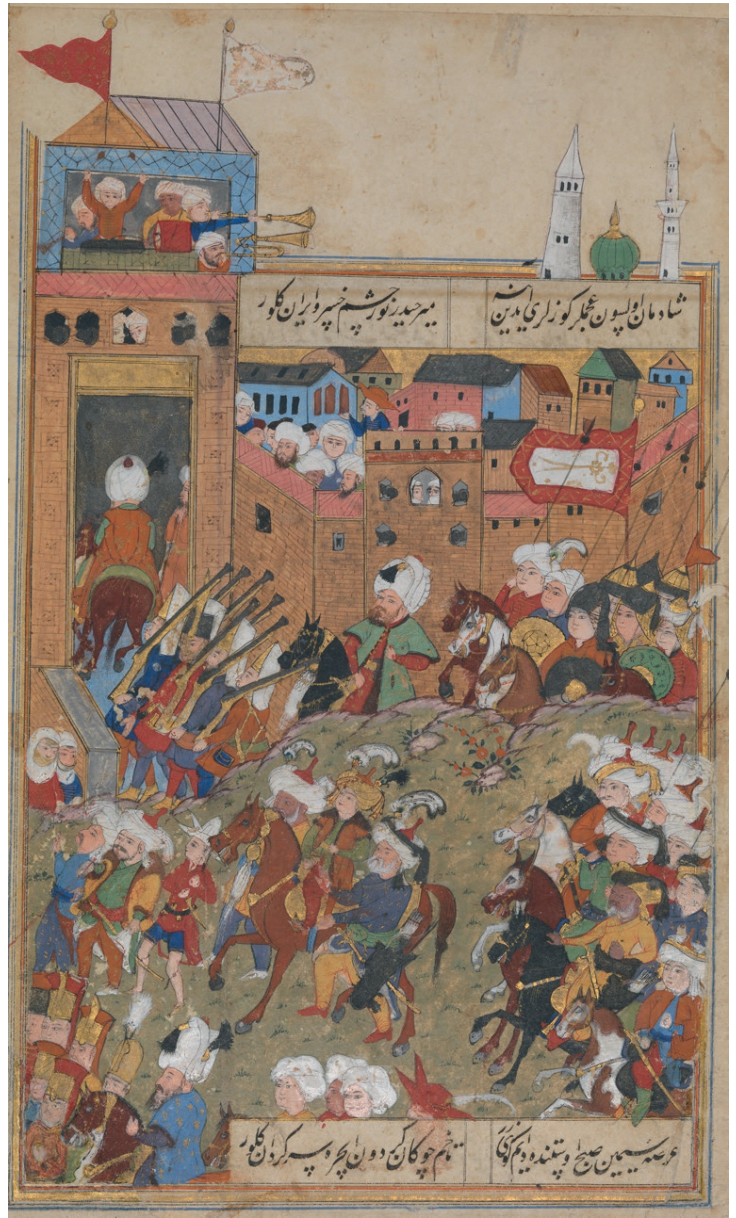

Resim 14: Haydar Mirza'nın İstanbul'a gelişi, Divan-ı Baki, Metropolitan Museum of Art 45.174.5

sakallı, sorguçlu sarıklı piyade yürümektedir. Siyah atının üzerinde ise Sokolluzade Hasan Paşa'yı görürüz. Oldukça kalabalık bir heyetle şehre giren kafileyi görmek için pek çok kişi toplanmıştır. Hatta minyatürün solunda iki kadın dahi görmek mümkündür. Kendisi de şehzadeyi karşılayan heyet arasında bulunan tarihçi Selanikli Mustafa Efendi de (öl. 1600?), kadınların bu kalabalık seyirci kitlesi arasında yer almasından ve hatta bu yüzden evlerine geç dönmelerinden dolayı sıkıntı yaşandığından bahseder. ${ }^{12}$

Üslup itibariyle değerlendirildiğinde XVI. yüzyıl sonunda Bağdat eyaletinde yapılmış olması muhtemel olan bu Divan'ın bir başka minyatürü, Şeyhülislam Ebussuud Efendi’yi bir iç mekânda otururken gösterir. Büyük bir sarı̆̆ı olan beyaz sakallı, kahverengi ve lacivert kıyafetli Şeyhülislam, bağdaş kurararak oturmuştur. Bir elinde tesbih tutar, diğer eliyle de

12 Mușțafa Selānikī, Tārīh-i Selānik̄̄, haz. Mehmet İpşirli (Ankara: Türk Tarih Kurumu, 1999), 219. 
karşısında oturan, önlerinde ve ellerinde kitaplar bulunan grubu işaret eder. $\mathrm{Bu}$ minyatür, Şeyhülislam için yazılmış Bahariyye'ye eşlik eder (Metropolitan Sanat Müzesi 25.83.9). Son olarak da yine aynı eserden günümüze kalmış olan üçüncü minyatür (Rhode Island Sanat Müzesi, 17.459) Kanuni Sultan Süleyman’a yazılmış kasideyi tasvir eder ve sultanı, bir alay sırasında at üzerinde gösterir.

Minyatürlü Bakî Divan'larında yer alan ve yukarıda bahsi geçen minyatürler, ağırlıklı olarak kasidelere eşlik etmektedir. Minyatürlerde padişahlara veya önemli devlet adamlarına yapılan vurgu ve verilen öncelik, bu kopyaları daha da değerli hâle getirmektedir. Bunların arasında Harvard Sanat Müzesi'ndeki eser, şaire verdiği ehemmiyet ve minyatürlerin kasideler yerine gazellerin yanında yer alması itibariyle diğer nüshalardan farklıdır. ${ }^{13} \mathrm{Bu}$ fark, divanların minyatürlerle tamamlanması konusunda ne gibi yaklaşımlar ya da seçenekler olabileceğinin sorgulanmasını sağlar. Nesir eserlerin yer verdiği hadiseleri tasvirlerle desteklemekelbette daha kolay hayal edilebilir; bu eserlerde minyatürün metinle birlikte okunması mümkündür. Ancak lirik şiir ile minyatürün eşleşmesi nasıl ele alınmalıdır? Kitabın, yani el yazmasının bir bütün olarak incelenmesinde lirik şiir ile minyatürün ilişkisine nasıl yaklaşılmalıdır?

\section{Sonuç}

Daha önce de bahsedildiği üzere, lirik şiiri minyatürlerle desteklerken sıklıkla tercih edilen kompozisyonlar genç âşıklar, meclis sahneleri, çevgan oyunları ya da ziyafetlerdir. Bunlar, lirik şiirin temsilinde kullanılması beklenen motiflerdir. Buna karşılık, şairin tasvirini yukarıda sözü edilen kompozisyonlarla doğal bir şekilde birleştirmesi açısından Harvard Sanat Müzesi'ndeki Bakî Divanı ayrıca ilgiye değer, nadir bir örnektir. Öte yandan hami ve eser ilişkisinin, divanlar ve bunların minyatürlerle tamamlanması meselesine yepyeni bir bakış açısı sunabileceğini unutmamak gerekir; bu makalenin kapsamı dışında kalan, XVII. yüzyıla ait, muhtemelen Safevi hükümdarı için hazırlanmış nüsha ve Sokolluzade Hasan Paşa için hazırlanmış olması muhtemel kopya dışında XVI. yüzyıl Osmanlı dönemine ait minyatürlü Bakî divanlarının kimler için hazırlandığı bilgisi mevcut değildir. Dolayısıyla, yazıda bahsi geçen divanlara eşlik eden minyatürlerin değerlendirilmesi konusunda gelecekte bu konularda yapılacak çalışmalar yeni ufuklar açabilecektir.

13 Harvard Sanat Müzesi'nde bulunan Bakî Divan'ının resimlerinde şairin bu denli ön planda olması durumuna, XVI. yüzyılın sonlarına doğru resimlenmiş başka Osmanlı eserlerinde de rastlarız. Buna örnek olarak 'Âşık

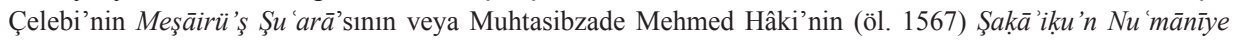
tercümesinin resimli kopyalarını verebiliriz. Aynı zamanda bu dönemde Osmanlı padişahlarının portrelerinde de belirgin bir yaygınlaşma söz konusudur. Resimli tezkirelerdeki şair portreleri sanki ikonik portrelerle olayları anlatan temsiller arasına sıkışmış gibidir. Bu tarz bir yaklaşıma Safevi dönemi lirik şiirinde rastlanmaz. Osmanlı dönemi resimli divanlarında ise nadir karşılaşılır. Meşāirü'ş Şu arā hakkında bakınız, Aslıhan Erkmen, “Mü’ellife Övgü: Musavver [Resimli] Tezkirelerde Yazar Portreleri,” Sanat Tarihi Yıllı̆̆ 23 (2011): 1-21; Şakāiłḳ’n Nu'mānīye hakkında bakınız, Tülün Değirmenci, “Osmanlı Sarayının Geçmişe Özlemi: Tercüme-i Şakā' ikū'n nu 'mānīye,’ Bilig (2008): 105-132. 


\section{Kaynaklar}

Fihrist, Vahid Paşa Kütüphanesi, No. 1031.

Sadiqi Beg Afshar. Majma' al-Khawass, ed. 'Abd al-Rasul Khayyampour. Tabriz: Akhtar-i Shumal, 1948.

Seyyid Mehmed Emin Vahid Efendi. Relation de l'ambassade de Mohammed Wahid Effendi. Paris: Firmin Didot, 1843.

Aslan, Mehmed. Antepli Ayni Divanı. İstanbul: Kitap Yayınevi, 2004.

Bal, Mieke and N. Bryson. "Semiotics and Art History." The Art Bulletin 73 (1991): 174-208.

Brookshaw, D. Hafiz and His Contemporaries: Poetry, Performance\&Patronage in Fourteenth-Century Iran. London, New York: I. B. Tauris, 2019.

Değirmenci, Tülün. “Osmanlı Sarayının Geçmişe Özlemi: Tercüme-i Şakā’ ikū’n nu 'mānīye.” Bilig (2008): 105-132.

Erkmen, Aslıhan. “Mü’ellife Övgü: Musavver (Resimli) Tezkirelerde Yazar Portreleri.” Sanat Tarihi Yılllğg 23 (2011): 1-21.

Kılıç, Filiz. Aşık Çelebi Meşairü'ş Şuara (Şairler Tezkiresi). İstanbul: İstanbul Araştırmaları Enstitüsü Yayınları, 2010.

Köprülü, M. F.. "Baki”. İslam Ansiklopedisi: İslam Alemi Tarih, Coğrafta, Etnografya ve Biyografya Lugatı, 2. İstanbul: Milli Eğitim Basımevi, 1961.

Küçük, Sabahattin. Baki Divanı. Tenkitli Basım. Ankara: Türk Dil Kurumu, 2011.

Roxburgh, David. "The Aesthetics of Aggregation: Persian Anthologies of the Fifteenth Century." Princeton Papers: Interdisciplinary Journal of Middle Eastern Studies (2011): 119-142.

Soucek, P. “Interpreting the Ghazals of Hafiz.” RES: Anthropology and Aesthetics 43 (2003): 146-163.

Tanınd, Zeren. "Transformations of Words to Images: Portraits of Ottoman Courtiers in the 'Divans' of Baki and Nadiri." RES: Anthropology and Aesthetics 43 (2003): 131-145.

Titley, Norah. Persian Miniature Painting and Its Influence on the Art of Turkey and India. The British Library Collections, Austin, Texas: University of Texas Press, 1983.

Uzunçarşı11, İsmail Hakkı. Bizans ve Selçukiylerle Germiyan ve Osman Oğulları Zamanında Kütahya Şehri. İstanbul: Devlet Matbaası, 1932.

Yıldız, Özlem. "Text and Image in the Divan of Baki: An Illustrated Manuscript in the British Library (Add. 7922)". MA Thesis, SOAS, 2018. 
